\title{
The only known egg of the Night Parrot? A molecular and morphometric assessment of an alleged egg from the Tanami Desert
}

\author{
Penny Olsen ${ }^{1 *}$, Jeremy Austin², Steve Murphy³ and Gavin Dally ${ }^{4}$ \\ 'Evolution, Ecology and Genetics, Research School of Biology, The Australian National University, Canberra \\ ACT 0200, Australia \\ ${ }^{2}$ Australian Centre for Ancient DNA, School of Biological Sciences, The University of Adelaide, North \\ Terrace Campus, Adelaide SA 5005, Australia \\ ${ }^{3}$ Research Institute for the Environment and Livelihoods, Charles Darwin University, Darwin NT 0909, \\ Australia \\ ${ }^{4}$ Natural Sciences, Museum and Art Gallery of the Northern Territory, Darwin NT 0801, Australia \\ ${ }^{*}$ Corresponding author. Email: penny.olsen@anu.edu.au
}

\begin{abstract}
The Night Parrot Pezoporus occidentalis is a much sought-after, recently 'rediscovered', endangered nocturnal parrot, endemic to arid Central Australia. Very little is known of its ecology, and its eggs have never been formally described. The literature on the eggs of the Night Parrot is collated here, and the provenance of an alleged Night Parrot egg found in the Tanami Desert, Northern Territory, in 1983 was assessed using DNA analysis and physical characteristics. Anecdotal reports from the late 19th-early 20th Century indicate that the Night Parrot lays a clutch of two to six roundish, white eggs. We suggest that its eggs are probably similar to and slightly larger than those of its congener, the Ground Parrot $P$. wallicus. The alleged Night Parrot egg was definitively identified by mitochondrial DNA analysis to be from the Brown Quail Synoicus ypsilophorus. This represents the first evidence of breeding by this species in the Tanami Desert, and lays to rest a long-standing misconception regarding the parrot.
\end{abstract}

\section{Introduction}

Recent events, including photographs of a live bird in 2013 and subsequent discovery of a small population(s), have focussed attention on the much sought-after, elusive Night Parrot Pezoporus occidentalis (Worthington 2013; Murphy 2015). The first specimen of this species was collected in 1845 on Sturt's Expedition to Central Australia (Sturt 1849). Through a quirk of fate involving the initial misidentification of Sturt's specimen, however, the species was not described until 1861 (from another specimen, collected during the Austin Expedition to the Murchison region of Western Australia in 1854: Gould 1861; Wilson 1937).

Museum collector Frederick Andrews is known or suspected to have collected the majority of the 28 Night Parrot skins in museums-some 22 at last count (Black 2012), all apparently in the 1870s, and all but one from the Gawler Ranges, South Australia. Since then, despite considerable efforts by ornithologists over many decades (e.g. Whitlock 1924), there have been only unconfirmed sightings, some more believable than others, from scattered locations across this species' range-the vast, arid interior of Australia. The exceptions are two desiccated bodies, each found in south-western Queensland, in 1990 and 2006, which provided tangible evidence that the Night Parrot was still extant (Boles et al. 1994; Cupitt \& Cupitt 2008; McDougall et al. 2009). The Night Parrot is listed as Endangered in several states and federally. Its breeding habits are poorly known and its eggs are undescribed (Forshaw \& Cooper 2002).

There is only one putative egg of the Night Parrot in collections. It was found abandoned in the Tanami Desert, Northern Territory, in 1983 (Gibson 1986). Despite its importance, its identity has never been confirmed.
There are a few anecdotal, secondhand descriptions of the eggs and clutch-size of the Night Parrot in the historical literature, often gleaned from Indigenous informants. Andrews (1883, p. 29) published the first description of the bird's nest and eggs:

During the day this bird lies concealed in the inside of a tussock or bunch of porcupine grass (Triodia), the inside being pulled out and a snug retreat formed for its protection. Here, also, its rough nest is formed, and four white eggs laid.

Whether Andrews actually saw the eggs himself is questionable. It is likely that, if he had, he would have taken them in his capacity as a collector for the South Australian Museum, if not for private sale, and there is no evidence that he did so. Instead, he may well have been repeating information on the nest and eggs gleaned from his Aboriginal guides.

Another seemingly reliable record dates from about the same period. Jack McDonald reported that in the 1870 s and 1880s, when he was living on Cootanoorina Station, south-east of Oodnadatta, far northern South Australia, the Night Parrot was fairly numerous. He described the eggs as "four in number, and white", about the size of a Crested Pigeon's Ocyphaps lophotes (McGilp 1931, p. 69).

The next record was by George Keartland, naturalist on the Calvert Expedition of 1896 to Central and northern Australia, whose notes were contained in a report on the birds of the expedition by North (1897). Keartland "ascertained from the natives that these Parrakeets lay four eggs in a loosely-made cup nest under the shade of the spinifex" (North 1897, p. 171).

A more questionable informant, W. Kelly, was the source of the only record of the Night Parrot from New South Wales. In August 1897, on a saltbush plain near Oxley, 
Kelly claimed to have found a nest with three eggs in a slight depression in the ground among "a type of porcupine grass"; three chicks hatched but died after one adult was mistaken for a quail and shot (Kershaw 1943, p. 196).

In the Wimmera of Victoria, Charles McLennan (a respected naturalist who wrote under the nom de plume 'Mallee Bird') saw the Night Parrot and reported that: "According to Jowley, an old aboriginal of this district, they live in a tussock of turpentine grass and lay from four to six eggs, rather round in shape" (Mallee Bird 1908, p. 52). There followed further reports, probably all based on McLennan's/Jowley's: five eggs (Campbell 1901) and five to six (Mattingley 1909) [see Menkhorst \& Ryan (2015) for a discussion on the validity of the Victorian records and the significance of Jowley's involvement].

Between 1912 and 1935, Martin Bourgoin, who was based at Meekatharra but travelled widely in his work for the Goldfields Water Supply, had several encounters with the Night Parrot in the upper Murchison region of Western Australia (Wilson 1937). In August 1927, he was searching for Dingo Canis lupus dingo pups around the breakaways at the head of Neds Creek when he saw eight Night Parrots, two brightly marked adults and six dull-green juveniles, on the ground at the mouth of a cave. Wilson (p. 84) continued:

\begin{abstract}
Mr. Bourgoin has never been able to find a nest ... Mr. Bourgoin questioned Bullocky and another old native named Masters and they told him that they had found the nests in tunnels under the spinifex and also in limestone caves. ... Bullocky said that they bred after big rains when there was plenty of feed and that the clutch was two to four white eggs.
\end{abstract}

Mathews (1948) described what he thought was a clutch of Night Parrot eggs in the Natural History Museum (NHM), London. Originally, they were from the collection of Henry Munt, a respected collector who specialised in white eggs, usually from captive birds. Mathews (p. 84) described the three eggs as "white, slight gloss, oval", with measurements $25.2 \mathrm{~mm} \times 20 \mathrm{~mm}, 25 \mathrm{~mm} \times 19.2 \mathrm{~mm}$ and $25.5 \mathrm{~mm} \times$ $19.5 \mathrm{~mm}$. The name 'Western Ground Parrakeet Geopsittacus occidentalis' appears on the museum label and in the accession book. The Night Parrot was referred to as the Western Ground Parrakeet for a few decades after Gould named the species in 1861.
Munt died in 1927, having built his collection since the late 19th Century (Kinnear 1927), so he would have purchased the eggs many years after their alleged laying date. Eggs of the rare Night Parrot would have been sought after, and it is entirely possible that Munt was misled or duped [see Walters (2005) for examples of fakeries in the NHM]. In 1862, the Night Parrot had only just been described, and the only two live Night Parrots definitely known to have been in captivity were sent to England after that date (Olsen 2009). The Munt catalogue, titled 'Parrot's Eggs', stated that the clutch was laid in captivity and the eggs themselves are inscribed 'C.G.P. 1862', perhaps an abbreviation for 'Captive Ground Parrot', that is, Pezoporus wallicus. A few Ground Parrots were kept in aviaries during the late 19th and early 20th Centuries (Cayley 1938). The egg dimensions are also consistent with those of the Mainland (eastern) Ground Parrot $P$. w. wallicus (Table 1). Hence, the clutch is most likely from a Ground Parrot. Forshaw \& Cooper (2002) also rejected this clutch as belonging to the Night Parrot.

Together, these records indicate that the Night Parrot lays a clutch of from two to six round white eggs, and that the eggs are perhaps about the size of those of the Crested Pigeon.

One final report remains and that is the focus of this article. In October 1983, during one of several biological surveys of the Tanami Desert, an abandoned egg was found near Green Swamp Well, at $19^{\circ} 15^{\prime} \mathrm{S}, 132^{\circ} 35^{\prime} \mathrm{E}$. Following consultation with ornithologists, it was concluded that the egg was probably from a Night Parrot (Gibson \& Cole 1983; Gibson 1986). The traditional owners of the area, the Warlpiri, called the bird 'Yurrupudpudpa'. However, only one of many interviewees had any further knowledge of the bird, and he reported that it laid a clutch of two to six eggs in a shallow depression under a spinifex bush. In the survey report, Gibson (1986, p. 188) summarised his find thus:

One egg collected from the ground between spinifex clumps, dimensions $31.0 \mathrm{~mm}$ length $\times 24.1 \mathrm{~mm}$ greatest width, oval in shape, off white and shiny, contained a small amount of dry matter; as no egg of this species is held by any collection in Australia absolute determination of its identity is not possible.

Table 1. Comparison of the Tanami Desert egg with eggs of Brown Quail, Crested Pigeon and Ground Parrots.

\begin{tabular}{|c|c|c|c|c|}
\hline & $\begin{array}{l}\text { Size } \\
\text { length } \times \text { greatest breadth, } m m(\mathrm{n})\end{array}$ & Shape & Colour & Source \\
\hline Tanami Desert egg & $31 \times 24$ & Oval & White & Gibson (1986) \\
\hline $\begin{array}{l}\text { Brown Quail } \\
\text { Synoicus ypsilophorus }\end{array}$ & $\begin{array}{l}\text { Highly variable. } \\
\text { Northern Territory } 29 \times 23(5) \\
\text { North Queensland } 30 \times 24(15)\end{array}$ & $\begin{array}{l}\text { Swollen oval, } \\
\text { pointed at } \\
\text { smaller end }\end{array}$ & $\begin{array}{l}\text { Bluish or yellowish } \\
\text { white, freckled } \\
\text { with brown; some } \\
\text { unmarked }\end{array}$ & $\begin{array}{l}\text { Marchant \& } \\
\text { Higgins (1993) }\end{array}$ \\
\hline $\begin{array}{l}\text { Crested Pigeon } \\
\text { Ocyphaps lophotes }\end{array}$ & $\begin{array}{l}32 \times 23(10) \\
33 \times 23(?)\end{array}$ & Elliptical & White & $\begin{array}{l}\text { Higgins \& Davies } \\
\text { (1996); } \\
\text { Beruldsen (2003) }\end{array}$ \\
\hline $\begin{array}{l}\text { Western Ground Parrot } \\
\text { Pezoporus wallicus flaviventris } \\
\text { Mainland (eastern) Ground Parrot } \\
\text { P. w. wallicus }\end{array}$ & $\begin{array}{l}\text { Western Australia } 27 \text { × } 22(3) \\
\text { Eastern mainland } 26 \times 21(6)\end{array}$ & $\begin{array}{l}\text { Round to oval or } \\
\text { elliptical }\end{array}$ & White & Higgins (1999) \\
\hline Captive ground parrot & $25 \times 20(3)$ & Oval & White & Mathews (1948) \\
\hline
\end{tabular}




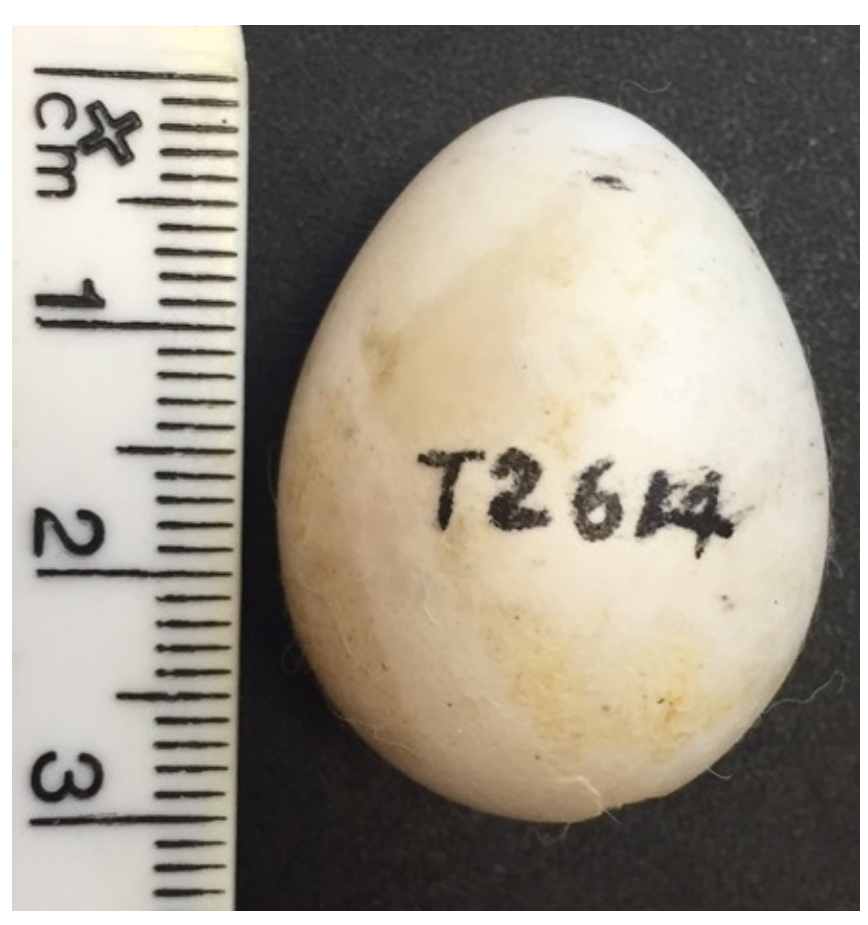

Figure 1. Egg collected by D. F. Gibson in the Central Tanami Desert, Northern Territory, in October 1983 (Museum and Art Gallery of the Northern Territory accession number T2614). Photo: Jeremy Austin

For the past 30 years, the record has been accepted as authentic (e.g. Joseph 1988; Higgins 1999), despite Gibson's uncertainty, or overlooked (Forshaw \& Cooper 2002; Beruldsen 2003).

In this paper we assess the identity of the Tanami Desert egg, using molecular analysis and a comparison of its characteristics with eggs of other potential candidate species.

\section{Methods}

The alleged Night Parrot egg (Museum and Art Gallery of the Northern Territory accession number T2614; Figure 1) was photographed and measured (with callipers, greatest length and breadth) and compared with the eggs of other potential candidate species (Figure 2).

It was molecularly assessed as follows. The egg was intact and the shell was drilled to obtain access to the contents. DNA extraction and PCR set-up were conducted in a clean-room laboratory with HEPA filtered positive air-pressure and ancient DNA workflows to minimise opportunities for contamination [see Austin et al. (2013) for details]. DNA was extracted from the interior of the egg using a DNeasy Blood and Tissue Kit (Qiagen) following the manufacturer's instructions. A biological sample was obtained by pipetting $1 \mathrm{ml}$ of ATL buffer (Qiagen) into the interior of the egg, allowing this to sit for 10 minutes and then pipetting out all remaining liquid. A short ( 150 bp) fragment of the mtDNA ND2 gene was PCR amplified and Sanger sequenced as described by Austin et al. (2013). Negative extraction (no tissue) and PCR (no DNA) controls were included, and no contamination was detected. The resulting sequence was searched against the National Centre for Biotechnology Information reference database of DNA sequences for birds.

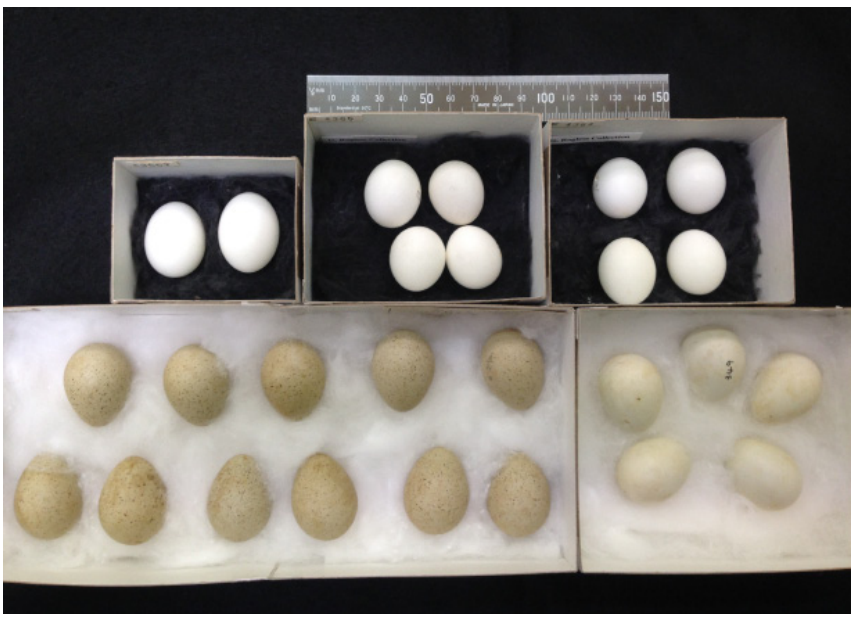

Figure 2. Eggs of the Crested Pigeon (one clutch), Eastern Ground Parrot (two clutches) and Brown Quail (two clutches) held in the Australian National Wildlife Collection (ANWC). Top, left to right: Crested Pigeon, 30 miles north-east of Mt Hopeless, South Australia (ANWC E3557); Eastern Ground Parrot, near Noosa, Queensland (ANWC E4365), and 6 miles north of Evans Head, Evans River, New South Wales (ANWC E4364). Bottom, left to right: Brown Quail (ANWC E6524), Bruny Island, Tasmania, and Suma Park, near Orange, New South Wales (ANWC E8527). Photo: Leo Joseph

\section{Results and discussion}

A single, unambiguous mtDNA ND2 consensus sequence was obtained for the Tanami Desert egg. It was $100 \%$ identical to a sequence from the Brown Quail Synoicus ypsilophorus (GenBank accession number AF222543: Dimcheff et al. 2000) and was 31 substitutions (24\% sequence divergence) different from a sequence from the Night Parrot (Pezoporus occidentalis; GenBank accession number HQ316877: Joseph et al. 2011).

In addition, the Tanami Desert egg is inconsistent in size, shape and colour with the eggs of the Ground Parrots (and what might be expected for the Night Parrot) and totally consistent with those of the Brown Quail (Table 1, Figures 1-2). As such, it appears to offer the first evidence of the Brown Quail breeding in that area. In his Tanami Desert bird list, Gibson (1986) included the Stubble Quail Coturnix pectoralis, and suggested that previous records there of the Brown Quail (Gee 1911; Bolton 1973 cited in Gibson 1986) were attributable to this species. However, several other sources regard the Brown Quail as an irregular visitor to the Tanami Desert following periods of rain (Marchant \& Higgins 1993; Barrett et al. 2003; GHD 2012).

The eggs of the Night Parrot could $P$ xpected to resemble those of its congener, the Parrot (average female weight 79 g: Higgins 1999), but slightly larger given that the Night Parrot appears to be a heavier bird (one live Night Parrot individual weighed 104 g: Steve Murphy pers. obs.).

We conclude that the suspected egg of the Night Parrot from the Tanami Desert is an egg of a Brown Quail and therefore has no further role in efforts to understand the biology of Night Parrots, the eggs of which remain undescribed. 


\section{Acknowledgements}

We thank Leo Joseph, Walter Boles and an anonymous referee for helpful suggestions on the manuscript and Leo for supplying images of eggs from the Australian National Wildlife Collection, CSIRO.

\section{References}

Andrews, F.W. (1883). Notes on the Night Parrot (Geopsittacus occidentalis). Proceedings of the Royal Society of South Australia 6, 29-30.

Austin, J.J., Joseph, L., Pedler, L.P. \& Black, A.B. (2013). Uncovering cryptic evolutionary diversity in extant and extinct populations of the southern Australian arid zone Western and Thickbilled Grasswrens (Passeriformes: Maluridae: Amytornis). Conservation Genetics 14, 1173-1184.

Barrett, G., Silcocks, A., Barry, S., Cunningham, R. \& Poulter, R. (2003). The New Atlas of Australian Birds. Birds Australia, Melbourne.

Beruldsen, G. (2003). Australian Birds: Their Nests and Eggs. Author, Brisbane.

Black, A.B. (2012). Collection localities of the Night Parrot Pezoporus (Geopsittacus) occidentalis (Gould, 1861). Bulletin of the British Ornithologists' Club 132, 277-282.

Boles, W.E., Longmore, N.W. \& Thompson, M.C. (1994). A recent specimen of the Night Parrot Geopsittacus occidentalis. Emu 94, 37-40.

Bolton, B.L. (1973). A Report on the Tanami Desert Sanctuary. Report for Territory Parks and Wildlife Commission, Darwin.

Campbell, A.J. (1901). Nests and Eggs of Australian Birds. Author, Sheffield, England.

Cayley, N.W. (1938). Australian Parrots: Their Habits in Field and Aviary. Angus \& Robertson, Sydney.

Cupitt, R. \& Cupitt, S. (2008). Another recent specimen of the Night Parrot Pezoporus occidentalis from western Queensland. Australian Field Ornithology 25, 69-75.

Dimcheff, D.E., Drovetski, S.V., Krishnan, M. \& Mindell, D.P. (2000). Cospeciation and horizontal transmission of avian sarcoma and leukosis virus gag genes in galliform birds. Journal of Virology 74, 3984-3995.

Forshaw, J.M. \& Cooper, W.T. (2002). Australian Parrots. 3rd edn. Alexander Editions, Robina, Qld.

Gee, L.C.E. (1911). General Report on Tanami Goldfield and District. Government Printer, Adelaide.

GHD (2012). Report for Old Pirate. Vegetation, Flora and Fauna Survey. Report to ABM Resources NL, GHD, Darwin. Available online: https://ntepa.nt.gov.au/_data/assets/ pdf_file/0008/290798/noi_twin_bonanza_appendix_a.pdf (retrieved 1 October 2016).

Gibson, D.F. (1986). A Biological Survey of the Tanami Desert in the Northern Territory. Conservation Commission of the Northern Territory, Alice Springs, NT.

Gibson, D.F. \& Cole, J.R. (1983). Fauna Survey of the Green Swamp Well Area, Tanami Desert. Conservation Commission of the Northern Territory, Wildlife Research Section, Alice Springs, NT.

Gould, J. (1861). On a new genus and species of parrakeet from Western Australia. Proceedings of the Royal Zoological Society of London 1861, 100-101.

Higgins, P.J. (Ed.) (1999). Handbook of Australian, New Zealand \& Antarctic Birds, Volume 4: Parrots to Dollarbird. Oxford University Press, Melbourne.

Higgins, P.J. \& Davies, S.J.J.F. (Eds) (1996). Handbook of Australian, New Zealand \& Antarctic Birds, Volume 3: Snipe to Pigeons. Oxford University Press, Melbourne.
Joseph, L. (1988). A review of the conservation status of Australian parrots in 1987. Biological Conservation 46, 261-280.

Joseph, L., Toon, A., Schirtzinger, E. \& Wright, T. (2011). Molecular systematics of two enigmatic genera Psittacella and Pezoporus illuminate the ecological radiation of AustraloPapuan parrots. Molecular Phylogenetics and Evolution 59, 675-684.

Kershaw, J.A. (1943). Concerning a rare parrot. Victorian Naturalist 59, 196.

Kinnear, N.B. (1927). Preface. Bulletin of the British Ornithological Club 47, iv.

Mallee Bird [McLennan, C.] (1908). Bush sketcher. A trip to sunset. The Australasian 4 April 1908, 52.

Marchant, S. \& Higgins, P.J. (Eds) (1993). Handbook of Australian, New Zealand \& Antarctic Birds, Volume 2: Raptors to Lapwings. Oxford University Press, Melbourne.

Mathews, G.M. (1948). Eggs of the Spinifex or Night Parrot. Emu 48, 84.

Mattingley, A.H.E. (1909). In the heart of the Mallee. Victorian Naturalist 26, 68-70.

McDougall, A., Porter, G., Mostert, M., Cupitt, R., Cupitt, S., Joseph, L., Murphy, S., Janetzki, H., Gallaher, A. \& Burbidge, A. (2009). Another piece in an Australian ornithological puzzle: A second Night Parrot is found dead in Queensland. Emu 109, 198-203.

McGilp, N. (1931). Geopsittacus occidentalis, Night-Parrot. South Australian Naturalist 11, 68-70.

Menkhorst, P.W. \& Ryan, E. (2015). C.H. McLennan ('Mallee Bird') and his Aboriginal informant Jowley: The source of early records of the Night Parrot in Victoria? Memoirs of Museum Victoria 73, 107-115.

Murphy, S. (2015). Shining a light: The research unlocking the secrets of the mysterious Night Parrot. Australian Birdlife 4 (3), 30-35.

North, A.J. (1897). List of birds collected by the Calvert Exploring Expedition in Western Australia. Transactions of the Royal Society of South Australia 22, 125-192.

Olsen, P. (2009). Night Parrots: Fugitives of the Inland. In: Robin, L., Heinsohn, R. \& Joseph, L. (Eds). Boom and Bust: Bird Stories for a Dry Country, pp. 120-146. CSIRO Publishing, Melbourne.

Sturt, C. (1849). Narrative of an Expedition into Central Australia, Performed under the Authority of Her Majesty's Government During the Years 1844, 5, and 6. Together with a Notice of the Province of South Australia in 1847. T. \& W. Boone, London.

Walters, M.P. (2005). My life with eggs. Zoologische Mededelingen 79, 5-18.

Whitlock, F.L. (1924). Journey to Central Australia in search of the Night Parrot. Emu 23, 248-281.

Wilson, H. (1937). Notes on the Night Parrot, with references to recent occurrences. Emu 37, 79-87.

Worthington, E. (2013). Queensland bird enthusiast presents museum with photos of elusive night parrot. $A B C$ News 4 July 2013. Available online: http://www.abc.net. au/news/2013-07-03/man-claims-to-have-filmed-the-rareaustralian-night-parrot/4796342 (retrieved 1 October 2016).

Received 10 February 2016, Accepted 4 March 2016, published online 20 October 2016 